\title{
Regeneration of BUET Campus: Vision 2035
}

\author{
Nasrin Nahar ${ }^{1}$, Maimuna Binta Reza², Proma Saha ${ }^{3}$ \\ 1,2,3 Undergraduate Students, Level-4,Term-II, Department of Urban and Regional Planning, Bangladesh \\ University of Engineering and Technology (BUET), Dhaka, Bangladesh \\ Dr. Ishrat Islam ${ }^{4}$, Professor, Ms. Nusrat Sharmin ${ }^{5}$, Lecturer, Mr. Rafsan Mashraky ${ }^{6}$, Lecturer \\ Department of Urban and Regional Planning, Bangladesh University of Engineering and Technology \\ (BUET), Dhaka, Bangladesh \\ Email for correspondence: nasrinnahar004@gmail.com
}

\begin{abstract}
BUET campus is in the heart of Dhaka. The physical expansion of the university over the last few years has been quite impressive. The aim of the study is to analyze the basic information and characteristics of Bangladesh University of Engineering and Technology (BUET), review the design principles for a universal university campus, set the vision and policies to evaluate the criteria for BUET campus regeneration and prepare a design proposal for BUET campus. BUET campus regeneration plan is needed to offer a unique opportunity to consolidate and control the unplanned development of the campus area. Evaluation criteria include factors such as campus characteristics, analysis of built structures, road network and existing problems and prospects of the campus etc. Second, third and fourth objective is to execute the task of preparation of a design proposal for BUET campus regeneration based on vision 2035. The study area includes the entire BUET campus area including main campus, teacher's quarters, staff quarters and residential dormitories. Both social and physical surveys were done as a method of data collection. Based on the vision and policies, the design proposals were segmented into three phases on the basis of time frame for the convenience of the further practical implementation task. After analyzing and comparing all the data and observations some recommendations have been provided at the end of the report. The study may help to understand the existing condition of BUET campus, the opportunities and threats which can be effectively evaluated for the regeneration of the campus area and thus can help to develop a useful and suitable planning proposal for the regeneration of the BUET campus area.
\end{abstract}

Key Words: Vision 2035, Evaluation Criteria, Regeneration, Design Proposals, Practical implementation

\section{INTRODUCTION}

The University of a country is the supreme institute which provides the highest order of education (Frowd, 2009). A university is an institution of higher education and research which grants academic degrees in various subjects and typically provides undergraduate education and postgraduate education (SCU, 2014). Throughout the world, universities change the society and remain the center of change and development. In Bangladesh, a number of universities have been set up so far theoretically for unlocking potential at all levels of society and creating a pool of highly trained individuals to contribute to the national development. Bangladesh University of Engineering and Technology (BUET) is the oldest institution for the study of engineering and architecture in Bangladesh. In this institution, every year more than 1000 students get enrolled in undergraduate 
and postgraduate programs to study in engineering, architecture, and planning field. The total numbers of teachers are about 500 . Academic activities are undertaken by seventeen departments under five faculties. Eleven departments offer undergraduate courses (Anonymous, 2017). All of the departments except the department of Humanities offer postgraduate courses. At present there are four institutes in BUET which offer postgraduate diplomas and master's degree. There are 7 research centers, 4 Directorates, 4 BUET Journals and Research Bulletins, 27 Student organizations, a Central library with a collection of over 1,32,000 volumes and 218 current periodical subscriptions, a cafeteria, a staff canteen, a teacher's club, a medical center and a post office in the campus. There are eight residence halls with varied facilities to provide housing for BUET students, teacher's quarter and staff quarter to provide accommodation facilities for teachers and students. There are also departmental libraries in each department and a hall library in each of the residence halls (Anonymous, 2017). The study provides an overview of the existing scenario of BUET campus, assessment of the existing problems and prospects and effective utilization of the strengths and opportunities to provide design proposals for BUET campus regeneration with a Vision for 2035. The study will help in visualizing the campus in a planned and organized way and at the same time will give a concept about the proper utilization of the opportunities and strengths and minimization of the existing problems of the campus. To establish a sustainable campus and maintain BUET's national reputation as an outstanding university with distinctive programs of excellence and services, vision 2035 for regeneration of BUET campus will achieve its goals through development and implementation of a centralized, efficient service system, strategic utilization of digital technology, modification of facilities, construction of structures and modification of spatial distribution etc. It will create a sustainable, car free, pedestrian friendly and less ecological footprint importing campus by the year 2035 .

\section{OBJECTIVES OF THE STUDY}

The Vision 2035 for regeneration of Bangladesh University of Engineering and Technology campus is expressed through integration of four objectives which build on the strategic priorities and provide clear direction for the future of the University.

- To analyze the existing condition of the entire BUET campus

- To create a well efficient transportation system in the campus and a car free environment in the campus arena

- To preserve the identity, enhance the aesthetic appeal and attain sustainability of the campus.

- To enhance and construct residential facilities and other services and create an efficient service system

The study is tried to be done in a systematic way by covering all the objectives but due to some limitations it was not possible to do detailed social and physical survey in a short time. And so opinions of people regarding problem they face and their aspiration and vision they have for the campus in future may not have come into light.

\section{METHODOLOGY OF THE STUDY}

The study was conducted from November, 2015 to December, 2015 aiming at formulating Regeneration plan for the campus area focusing 
a concrete Vision 2035. For analyzing existing condition of the campus arena both primary and secondary level data were collected. Physical survey was conducted on the physical characteristics of the campus in order to evaluate the existing scenario along with the present problems and prospects. Visits were made at different locations within the campus two to three times in two weeks, both in holidays and working days. For the purpose of identifying the details required for conducting the study, a structured checklist was used which was prepared in accordance with the objectives declaring specific variables in an arranged way. For the study, some basic information regarding the university campus was collected from the university website and other secondary sources. Such information include some data regarding the basic campus characteristics such as the year of establishment of different buildings as well as some administrative information comprising the number of teachers, the number of students etc.

The information was included into the checklist in order to determine the appropriate data for the study. From field observation and secondary source, data on building height, ground coverage area, plot area, building condition were collected. Traffic survey like volume survey was conducted at different entry gates of the campus in three different times $9 \mathrm{am}, 1 \mathrm{pm}$ and $5 \mathrm{pm}$ to analyze the pattern of traffic flow in the campus. In addition to this data on road width, footpath width, road condition, condition of open spaces were also collected. Collected data were mainly used for analyzing the existing condition of BUET campus and represented in graphical, tabular and Map form using SPSS, Microsoft Excel and AutoCAD to attain the objectives. Final regeneration plan for BUET campus was prepared analyzing the data.

\section{EXISTING SCENARIO OF BUET CAMPUS AREA}

To have a clear idea about the present condition of the BUET campus area the following key existing indicators were explored.

\section{CAMPUS CHARACTERISTICS ANALYSIS}

Campus Area: BUET campus covers an area over 82.21 acre. Almost half of the total area is used as open space (47.16 acre) whereas built area occupies 22.73 acre and rest of the area which covers 12.32 acre are used as pathways and roads.

\section{Year of Establishment of Different Buildings in the Campus: Almost 36 buildings of the campus were built in between year of 1971 to 1980. After '80s only 13 buildings are built. 9 buildings which were built before the liberation war were needed to be redesigned.}

\section{ANALYSIS ON OPEN SPACE OF THE AREA}

The character of the campus represents a Romantic Naturalism, a landscape style employed on many spaces of BUET campus. The campus is organized by a series of informally connected outdoor spaces that have evolved incrementally as the campus developed. Under BUET campus, the total open space occupies area of $57.35 \%$ (47.16 acre) of the total campus area, $26.53 \%$ of open spaces is planned and well marinated whereas $23.86 \%$ can be marked as III maintained open space. Planned and well maintained open spaces are categorized as active and passive open space according to use and ill-maintained open spaces area categorized as negatively used and vacant open space. 


\section{BUILT STRUCTURE ANALYSIS}

Space Use and Built Structure Occupancy: Depending on the usage of the buildings the built area is subdivided into different parts. The area for residential use covers almost 10.09 acre and the academic usage covers 9.73 acre. There is also some other recommendable usage like commercial, institutional usages. The area used for residential purpose is remarkable in BUET campus.

\begin{tabular}{|c|c|}
\hline Residential use & 10.09 acre $(44 \%)$ \\
\hline Academic use & 9.73 acre $(43 \%)$ \\
\hline Commercial use & 0.68 acre $(3 \%)$ \\
\hline Structure & 0.82 acre $(4 \%)$ \\
\hline Others & 0.43 acre $(02 \%)$ \\
\hline
\end{tabular}

Figure 01: Built Structure Occupancy (area) (Source: Field Survey, 2015)

Residential Dormitories: Space allocated for residential use covers 7 male student dormitory, 1 female student dormitory, teachers' quarter and staff quarter. In case of students' dormitory all female students can't access residential facilities due to lack of enough dormitory facilities. In case of Teachers quarter residential facility is not allocated for single male and female teachers. The quality of living is not so good for the students and staffs especially whereas teacher's quarters are comparatively well maintained than the student's dormitories and staff quarters. In case of Female students dormitory plot area (1.26 acre) is much larger than building ground coverage area (.62 acre). Similar case is observed in case of Dhakeshwari and Bakshibazar teachers' quarter where plot area is respectively 6.39 and 4.49 acre whereas building ground coverage covers only 1.06 and 2.06 acre respectively. So with proper planning more students and teachers can be provided with residential facility within the campus premises more efficiently. In the campus area significant variation can be seen in case of heights of buildings which vary from one to twelve stories. Recreational facilities provided are insufficient and ill maintained. Inadequate parking space is provided for different vehicles. Most of the buildings of the staff quarter are old, backdated and lack adequate facilities. The drainage system of the site is poorly maintained.

\section{Number of Stories Associated with Ground} Coverage: Total ground coverage for 1 storied building is of 4.34 acres and it is 102 in number whereas 4 storied buildings are of less in number (24) but covers a major amount of space (5.81 acre). There are 12 buildings in BUET above 6 stories. In staff quarter large portion of the site remains underutilized.

\section{ROAD NETWORK ANALYSIS}

Road and Footpath Details: The current road types that exist in BUET are the major distributor road and the access road. The only major distributor road that passes through the main campus area is the Asian Highway. The other major distributor roads are the Bakshi Bzar road and the Shahid Sarani. The major and access roads have adequate width. Footpath is available for the movement of the pedestrians but the footpath width varies. In campus area the footpath is not well-designed and not adequate. But the positive thing is that enough space is provided for road networking.

Traffic Flow: From volume survey at different entry gates of the campus, pattern of traffic inflow 
Table 01: Table showing Road network details of the campus area

\begin{tabular}{|l|l|l|l|l|l|}
\hline Road Type & \multicolumn{1}{|c|}{ Material } & $\begin{array}{c}\text { Area } \\
\text { (acre) }\end{array}$ & \multicolumn{1}{|c|}{$\begin{array}{c}\text { Area } \\
\text { (in percentage) }\end{array}$} & $\begin{array}{c}\text { Road Width } \\
\text { (in feet) }\end{array}$ & $\begin{array}{c}\text { Footpath } \\
\text { Width( in feet) }\end{array}$ \\
\hline - Major Distributor & Pitch & 3.86 & $4.7 \%$ & 60 & $6-9$ \\
\hline - Access Road & Pitch, Concrete & 8.46 & $10.29 \%$ & $20-25$ & $2-6$ \\
\hline
\end{tabular}

and outflow and their significant impacts are tried to be explored in this study. At 9 a.m. both traffic inflow and outflow was found to be high at campus main gate and entry gate adjacent to BUET field, at $1 \mathrm{pm}$ traffic inflow increases at Hall main gates and Staff quarter main gate and traffic outflow increases significantly at campus main gate.

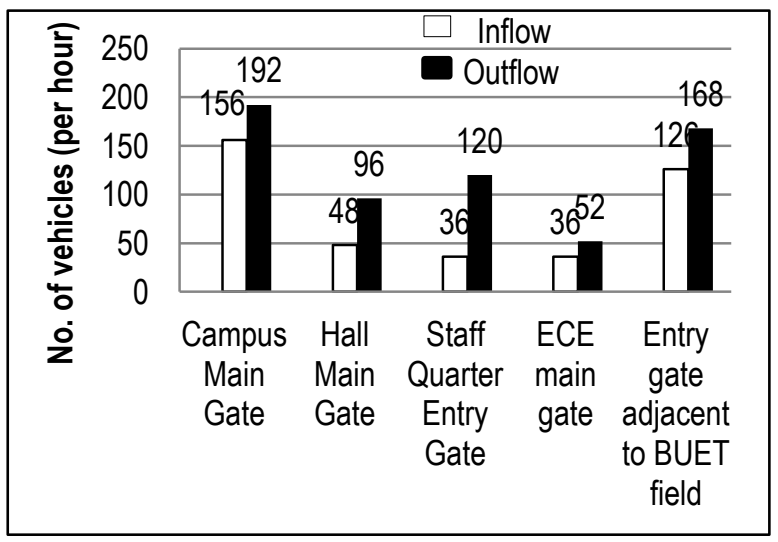

Figure 02: Inflow and outflow of entry gates at 9a.m. in BUET campus

(Source: Field Survey, November, 2015)

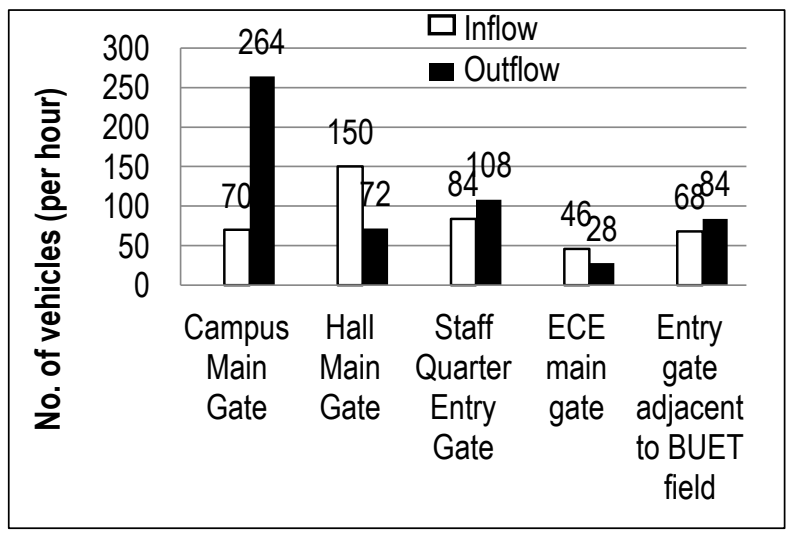

Figure 03: Inflow and outflow of entry gates at 5p.m. in BUET campus

(Source: Field Survey, November, 2015)
At $5 \mathrm{pm}$ traffic outflow is found to be high at main campus gate and traffic inflow is found to be high at teacher's quarter entry gate. This traffic flow not only hampers the smooth movement of the people but also lessens the aesthetic beauty of the campus.

Parking Details: Parking is not at all desirable in the campus area. In BUET campus takes place off-street and on street car parking. Everyday near-about 600 cars are parked in BUET campus. The spaces used for on-street car and bicycle parking are in front of Cafeteria, Civil building, EME building, URP building, ECE building, OAB, Chattri hall and Backyard of Civil building, Sonali bank etc. Spaces used for offstreet parking are central parking garage of BUET campus and garages allocated in teacher's quarter. Adequate, planned as well as designated parking is not provided. Hence several places including the spaces in front of the cafeteria, library and $O A B$ building are used for parking hampering the pedestrian flow.

\section{EXISTING PROBLEMS AND PROSPECTS}

Garbage disposal system of the campus is not sufficient and well distributed. Separate walking route is not provided for pedestrian circulation. Insufficient lighting facility enhances the risk of crime providing an insecure atmosphere. Plentiful plantation in the campus arena keeps the environment cool. The total campus area is divided into separate zones which help the students function effectively. 

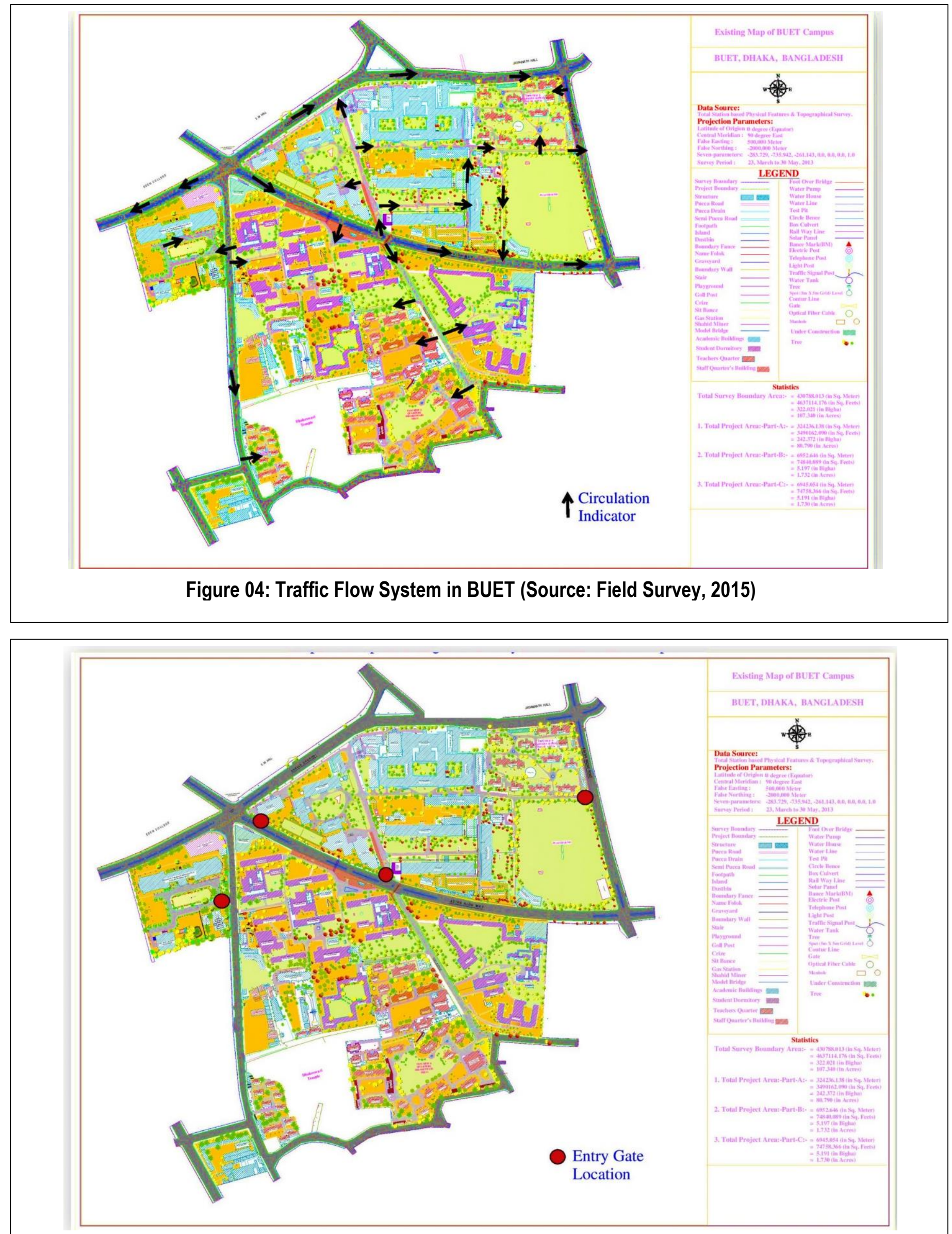

Figure 05: Location of Main Entry Gates in BUET (Source: Field Survey, 2015) 
Well distributed drainage channels are provided throughout the whole campus. Transportation facility is provided by the university for the students. Sufficient utility facilities are provided for the students in the campus. In the students dormitories natural and artificial landscaping beautifies the aesthetic appearance of the site. Certain landmarks provided in each dormitory give them a specific identity. Parking facility is provided for the students. Amenities for indoor and outdoor sports are provided for the students.

\section{REGENERATION OF BUET CAMPUS: VISION 2035}

Vision 2035 for regeneration of Bangladesh University of Engineering and Technology campus moves forward with a view to creating a sustainable, car free and pedestrian friendly campus and developing well efficient centralized transportation and service system in the campus and maintaining BUET's national reputation as an outstanding university with distinctive programs of excellence and services.

To implement the Vision 2035 for Regeneration of BUET campus and objectives under this vision, the design proposals outlines the University's long-range aspirations to construct new facilities, renovate existing spaces, creating well efficient transportation and central service system and preserving the identity of the campus arena. To ensure efficient implementation of the design proposals and goals time frame of the project has been divided into three phases

\section{PHASE 1 DESIGN PROPOSALS (2016-2020)}

BUET market will be shifted in the 3 storied building located at the north side of Suhrawardy Hall to enhance the service facility. A canteen at the north side of ECE building with .23 acre ground coverage will be provided. BUET central cafeteria will be extended at its south west side with an area of .13 acre and semi-permanent shaded, open air environment will be created there.

Multistory solar parking will be constructed at the south side of existing BUET market which will help to reduce Excessive energy consumption at ECE building. Car of students, teachers, staffs and guests will be parked here. Parking fare policies according to time will be imposed for parked vehicles

Space for bi-cycle parking will be provided on four locations in the campus-at backyard of civil department building, east side of teacher's club and at the north side of ECE building entrance. Parking fare according to time will be imposed on these parking lots. Space for bicycle parking will be provided in the ground floor of Sher-e Bangla hall, Suhrawardy hall, Titumir hall and M.A. Rashid hall.

A new 6 storied building with 21780 square feet will be constructed at the north side of Chattri hall to accommodate the existing students. Teachers quarter's 4 no and 9 no building will be relocated at Dhakeshwari teachers quarter. A new 8 storied building with 4813.99 square feet ground coverage will be constructed at the north side of 8 no quarter building to accommodate residents of 1 no and 5 no teacher's quarter building. Total 3 new 4 storied academic building comprising of total 51,779 square feet ground coverage will be constructed in the place of Old academic building with well-designed open spaces.

Tennis courts, basketball court, cricket courts, volleyball courts will be constructed at Sher-e Bangla hall, Suhrawardy Hall, Titumir Hall and M.A. Rashid Hall to enhance recreational facilities, provide sports facilities to the students residing in this halls and ensure proper utilization 
of the leftover open spaces in this student dormitories. The huge 3 trash bins at the major road outside main gate will be removed and relocated elsewhere.

Landscaping will be done in several vacant and ill-maintained open spaces except Old academic building plot, Chattri Hall, Ahsanullah Hall, Shahid Smrity Hall, Nazrul Hall, Bakshibazar and Dhakeshwari residential area teachers quarter, Staff quarter and Azad quarter through plantation, provision of sitting arrangements, plazas, fountains, lighting. This will help to increase accessibility and create a sense of belongingness.

\section{PHASE 2 DESIGN PROPOSALS (2021-2030)}

On-campus automobile vehicle parking will be removed and the campus area will be a completely car free area restricting car in the campus. The main campus area, West Palashi campus area, part of Asian highway from Palashi intersection to Bakshibazar intersection and road at the east side of Chattri hall and staff quarter will be declared as the car free zone. Only bicycle will be allowed to enter this zone. Proper road signs, marking and regulatory system will be provided to ensure the well maintenance of car free and pedestrian friendly zone.

Separate Pedestrian pathways and bicycle routes will be provided to promote walking and cycling oriented environment. Pedestrian pathways will be designed in the campus. Footpath will be extended at the west side of BUET main gate, on south side of Asian highway, beside Ahsanullah Hall, Chattri Hall and staff quarter. Footpath condition will be enhanced to ensure safe pedestrian movement.

Central University transport parking will be relocated at north side of entry gate near BUET field at the place of 4 and 9 no teacher's quarter building plot. University transport will be allowed to enter the campus only through the gate at the north side of BUET field. Transport facilities will be enhanced by providing transportation to different routes at 9 am and $10 \mathrm{am}$ in the morning. New university vehicle required for enhancing transport facilities will be accommodated in the new Central University parking lot.

A foot over bridge will be constructed near the Palashi intersection which will start from front side of Sonali bank and end at footpath near ECE building. It will connect Main campus with west Palashi campus and ensure safe pedestrian movement through the Palashi intersection.

Old Chattri Hall will be demolished and another 6 storied building with $12211 \mathrm{sq}$ feet ground coverage will be constructed which will accommodate 240 new female students. Ahsanullah Hall and Nazrul Hall building will be demolished after shifting the students of these halls to the new constructed student center building. These two halls will be redesigned by providing extra accommodation for 800 students and sufficient well designed open space and play courts. 15204.26 square feet ground coverage for Ahsanullah hall building and 20518.44 square feet ground coverage for Nazrul hall building will be provided. Both the buildings will be vertically extended to 8 storied in height.

A well designed BUET main gate will be constructed to preserve the sense of identity of the campus. Identifiable landmarks in front of every department, student dormitories, teacher's quarter and staff quarter along with signage will be constructed to give an instant image and preserve identity of the particular departments and spaces. Landscaping will be done in Chattri 
Hall, Ahsanullah Hall, Nazrul Hall and Shahid Smrity Hall and new academic building plot through providing plantation, sitting arrangements, plazas and landscape lights. Pathways and active open spaces will be created in these halls through landscaping.

\section{PHASE 3 DESIGN PROPOSALS (2031-2035)}

Two new 6 storied building with 2080.71 square feet at the north side of 23 no teachers quarter will be constructed for providing residential facility for single male teachers and another 6 storied building with 2840.86 square feet ground coverage at the place of 1 no teachers' quarter building will be constructed to accommodate single female teachers. These two buildings will accommodate approximately 30 male teachers and 40 female teachers.

Landscaping will be done in Bakshibazar and Dhakeshwari residential area teacher's quarter, staff quarter and Azad quarter through providing plantation, sitting arrangements and landscape lights to increase accessibility and providing environment for spiritual development. Recycle bins will be provided in different space in the campus to promote recycling process.

Tennis courts, basketball court, cricket courts, volleyball courts will be constructed at Ahsanullah hall, Nazrul hall and Chattri hall. Gallery will be constructed around BUET field. Planned play lot and parks will be provided in Staff quarter, Azad quarter, Bakshibazar residential area teachers' quarter and Dhakeshwari residential area teacher's quarter to serve recreational purpose of the residents. Vacant space of staff quarter at the west side of Azad quarter will be redesigned to be used as teacher's quarter with well-designed open space, landscaping and play lots. All the semi pucca structures will be demolished in these staff quarter.

The campus buildings will import less ecological footprint and sustainability will be attained through strategic utilizing of digital technology, establishing alternative energy source biomass technology, solar plants and designing rooftop garden at the roof of every building. Existing Rainwater harvesting plant will be renovated and maintained in future.

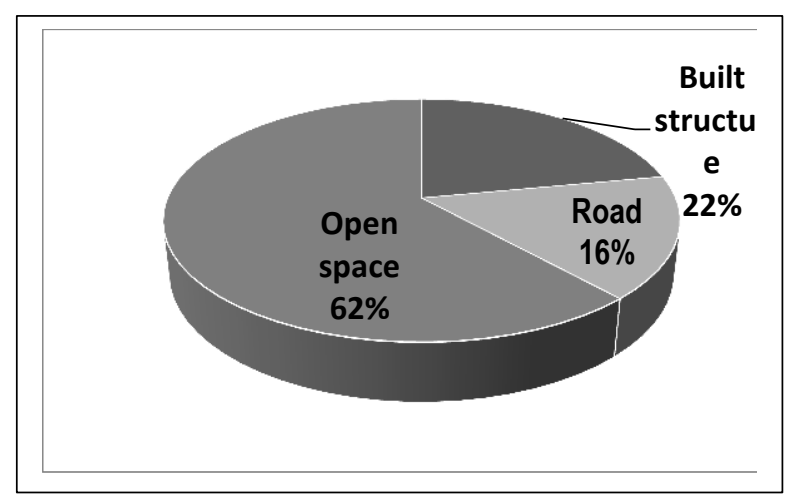

Figure 06: Proposed Campus Characteristics

In the proposed plan residential use ground coverage will reduce from 10.09 acre to 6.92 acre despite of providing extra accommodation facilities for teachers and students. Academic use ground coverage will reduce from 9.73 acre to 8.7 acre through reconstruction of Old Academic Building. Commercial use will increase from .68 acre to 1.04 acre as cafeteria facility will be enhanced in the proposed plan. Institutional and other uses remained unchanged in the proposed plan. A large portion of semi pucca structure will be demolished in the proposed plan. Road area will increased from 12, 32 acre to 13.38 acre as more pedestrian walkways were designed in the campus. Open space area will increase from 47.16 acre to 50.76 acre by 
Table 02: Table Showing Road network details of the proposed campus area

\begin{tabular}{|l|l|l|l|l|}
\hline Road type & Area (in acre) & Area (in percentage) & Road width & Footpath width \\
\hline Major distributor & 3.86 & $4.7 \%$ & 56 & $8-10$ \\
\hline Access road & 9.52 & $11.5 \%$ & 20 & $6-8$ \\
\hline
\end{tabular}

proper management and planning with all the vacant and ill-maintained open spaces and ancillary spaces between buildings Planned road network is a prior requirement for establishing a well efficient transportation system and creating a car free campus.In the proposed plan road infrastructure comprises of 13.38 acre among which access roads will increase from 8.46 acre to 9.52 acre as more pedestrian pathway and walkways are designed in the campus.

Footpath width of major distributor road in the proposed plan will be from 8 to 10 feet which is from 6 to 9 feet in the existing situation and footpath width of access road in the proposed plan is 6 to 8 feet which is from 2 to 6 feet in the existing situation.

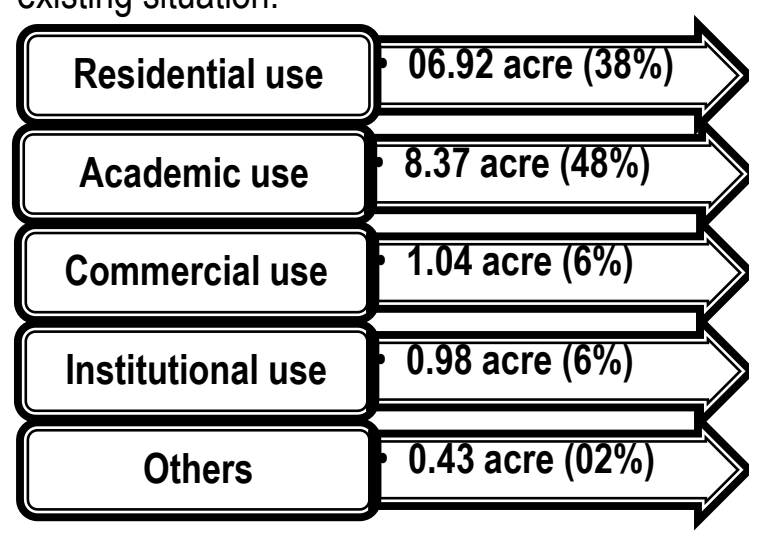

\section{Figure 07: Proposed Built Structure Occupancy}

From the section where existing condition was discussed it is observed that $26.5 \%$ open spaces are planned and well maintained and $23.8 \%$ are ill maintained with respect to the total area. In the proposed plan open space will increase from
47.16 to 50.76 acre and by planning all the vacant, ill maintained open spaces and ancillary spaces between built structures and renovating the well maintained open spaces active open spaces will be $26.5 \%$ and passive open space will be $23.8 \%$ with respect to the total campus area.

\section{CONCLUSION}

According to findings of data analysis, under the umbrella of research objectives and research checklist conclusion have been drawn in this section.

The higher education sector is undergoing a fundamental transformation in terms of its role in society, mode of operation, and economic structure and value.

There are many issues for judging the standards of a university- physical infrastructure and campus environment, availability of required facilities are some of them. Physical facilities are very important for higher level education. A wellstructured and environmental-friendly campus with sufficient classroom and other necessary facilities are very much relevant.

In order to grow and increase its market share in an increasingly competitive sector, the University recognizes that it needs to increase the quality of its 'offer' in all aspects of University life and in particular, the 'student experience'. This includes the quality of its teaching and learning facilities, residential and recreational facilities and the wider physical campus environment; all of which 


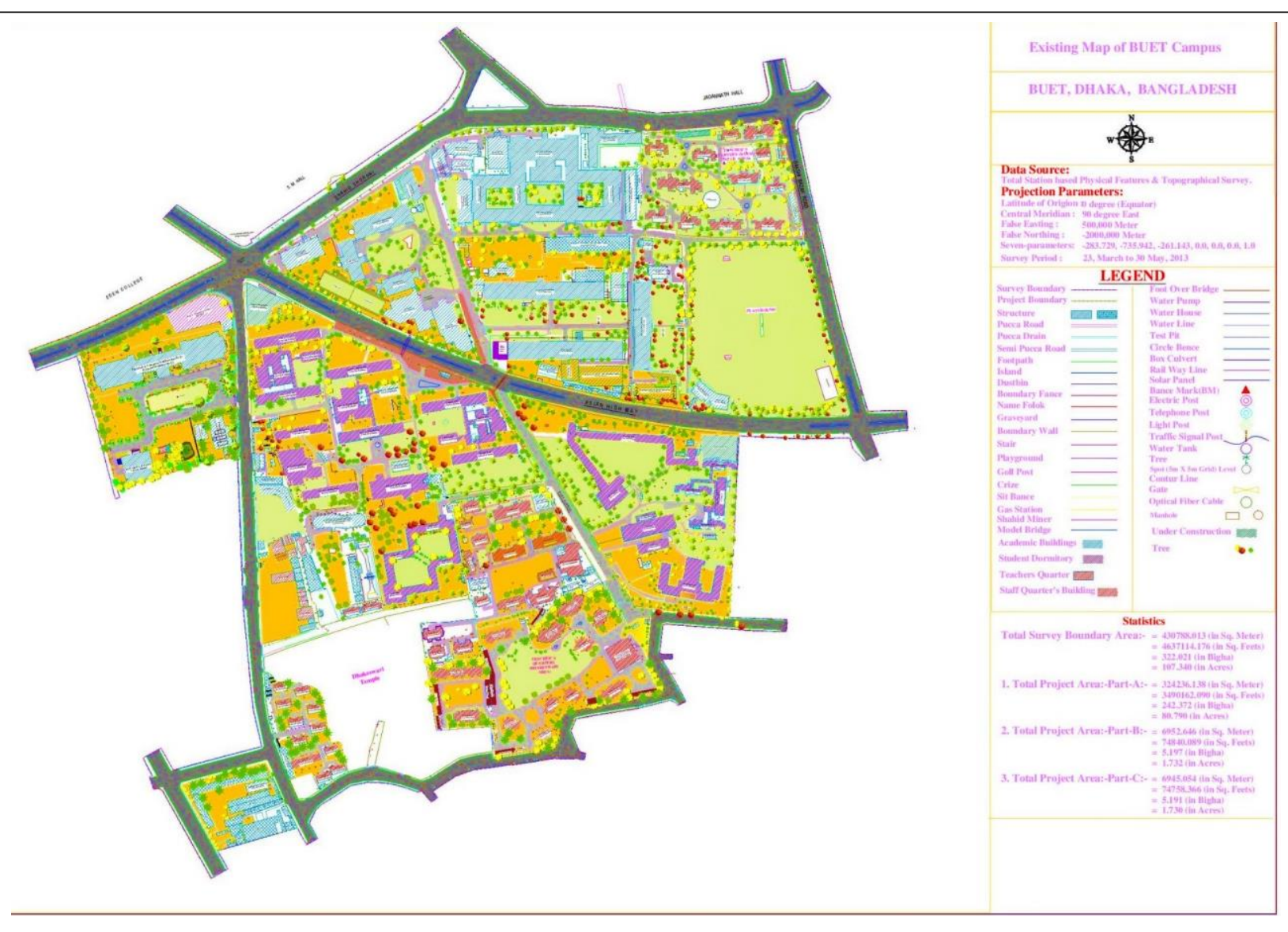

Figure 08: Existing Map of BUET Campus (Source: Field Survey, 2015)
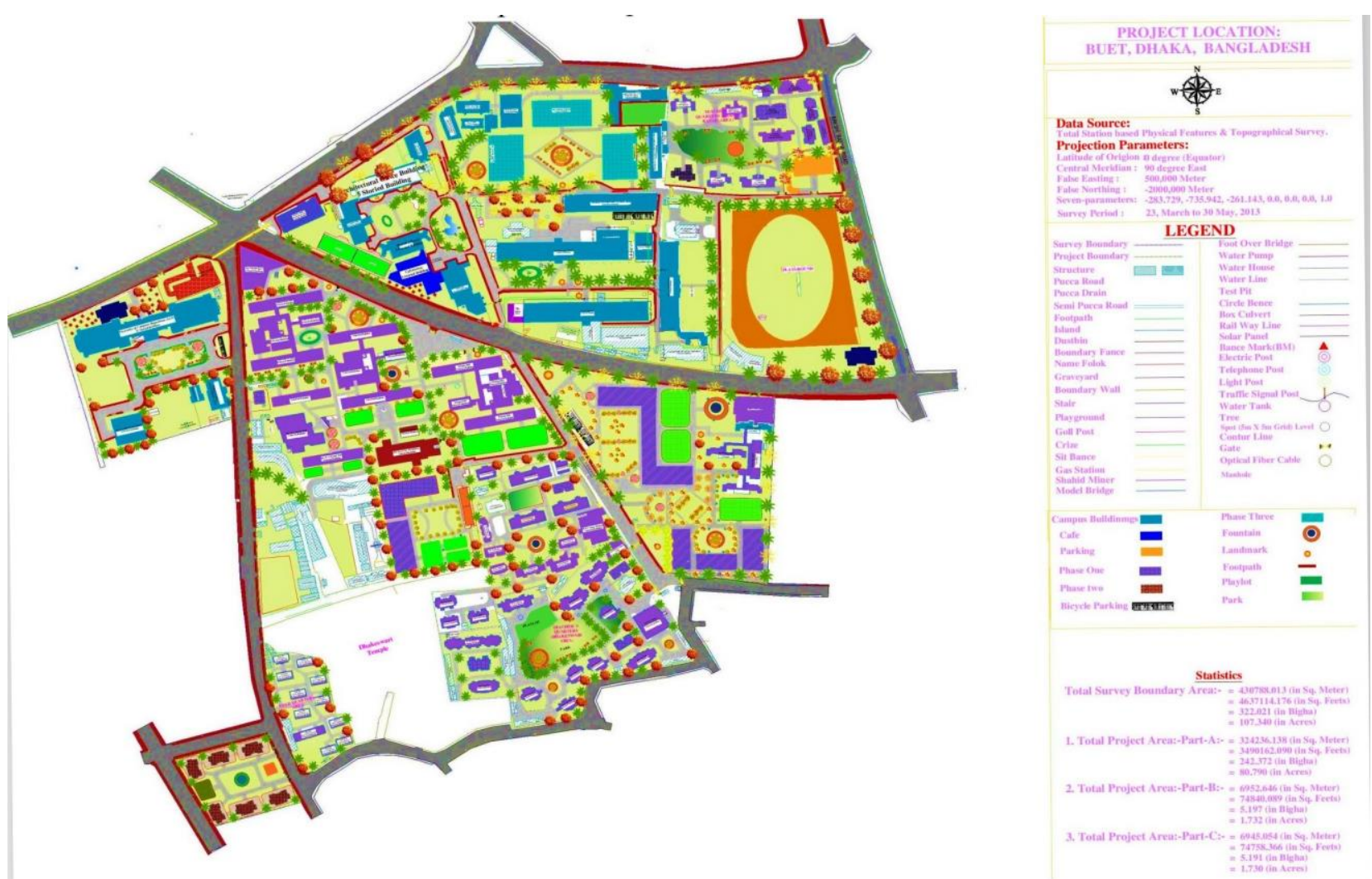

Figure 09: Proposed Map of BUET Campus for Year 2035 
are now very important factors for students in deciding where they wish to learn and study. In response and in order to accommodate future growth and physical improvement, this study has endorsed a new 'vision' and proposes a campus plan which expresses this vision and the transformational change required in physical terms over a twenty year life-cycle.

\section{REFERENCE}

Frowd, A. (2009), "SPACE PLANNING GUIDELINES”, Tertiary Education Facilities Management Association, URL: http://www.tefma.com/uploads/content/2 6-TEFMA-SPACE-PLANNINGGUIDELINES-FINAL-ED3-28-AUGUST09.pdf , accessed on October 5, 2015
SCU (2014), "CAMPUS DESIGN STANDARDS" , URL: http://facilities.scu.edu/planning_projects/ planning/design_standards/, accessed on October 7, 2015

USNews (2015), "Santa Clara University Campus Services", URL: http://colleges.usnews.rankingsandrevie ws.com/best-colleges/santa-clara- , accessed on October 7, 2015

Anonymous (2017), "Faculties of BUET", URL: http://www.buet.ac.bd/Department/Facult ies, accessed on May 6, 2017 